\title{
Inspiration and Consumption Behavior of Consumers for Enhanced Food Security Management
}

\author{
Chuleewan Praneetham \\ Suratthani Rajabhat University, Thailand, E-mail: chuleewansru@gmail.com \\ Intareeya Leekancha \\ Suratthani Rajabhat University, Thailand, E-mail: intareeya@hotmail.com
}

Doi:10.5901/mjss.2015.v6n6s2p453

\begin{abstract}
This paper aims (i) to study inspiration and consumption behavior of consumers for enhanced food security management, (ii) to investigate factors influencing consumers' behavior on food security management, and (iii) to study the relationship between inspiration and behavior of consumers on food security management. The sample of this study consisted of 400 consumers in Muang district selected by simple random sampling technique. Questionnaires were used for data collection. Means, percentage, standard deviation, $t$-test, One-Way-ANOVA and Pearson's Product Moment Correlation were used to analyze the data. The findings indicated that: 1) the overall inspiration and consumption behavior of consumer for enhanced food security were at good level, 2) behaviors on food security management were influenced by the level of education, age and marital status ( $p<0.01)$, and 3$)$ the inspiration and behavior of consumers on food security management were significantly and positively correlated at the level of .01. In achieving food security, everyone should be aware and more concerned of the issues that will affect the food security.
\end{abstract}

Keywords: Inspiration, Consumption Behavior, Food Security.

\section{Introduction}

From birth to death human needs to get enough food, both in terms of quantity and quality. Globalization has caused an impact on food security in many dimensions. Canadian International Development Agency (2014:1) stated that, rapid population growth, fluctuations and expansion of economic, subsistence income, food prices, and increased fares and prices of agricultural products amplify food insecurity. Moreover, climate change issue is an important environmental and socioeconomic driver of food insecurity (Braun et al., 2008: 5; Beddington, et al., 2011: 4). Increasingly, climate change affects the fundamental Earth systems, agricultural production, and food supplies. Food crisis threatens the livelihoods of human being.

Food security has become a global problem. In the first decade of the 21st century global food insecurity situation is becoming more severe. The world food situation is found to be an extremely issue. Because food insecurity causes increasing mortality, health impacts, disease, disability, and enormous reduction in human potential. (Nelson et al., 2010: 15; Thiengkamol, 2012: 35; Renliang, 2013: 102). Therefore, the world will need to produce more food in order to deliver adequate and sufficient food to everyone and to meet the demand of world's population (Beddington, et al., 2011: 4). The Food and Agriculture Organization (FAO) defined food security that it is a situation that exists when all people, at all times, have physical, social and economic access to sufficient, safe and nutritious food that meets their dietary needs and food preference for an active and healthy life (FAO, 2006: 1; Pongsrihadulchai, et al., 2013: 61). Generally, there are different important elements to accomplish the food security for people. The four dimensions of food security can be identified as food availability (sufficient quantities, production, distribution and exchange), food access (affordability, allocation and preference), food utilization (nutritional and societal values and safety), and food stability (availability and access dimensions of food security) (FAO, 2006: 1; Thiengkamol, 2011: 162).

Thailand, as a food surplus country, is the world leading exporter who exports several food crops. Thailand has created self-sufficiency in domestic production to ensure its food security mainly for human consumption, animal feed and bio-energy (Tumpracha, et al., 2012b: 311; Pongsrihadulchai, et al., 2013: 31). However, in rural area, there is a tendency of food vulnerability. In agricultural community, the food security is a condition in which all community residents can obtain a safe, culturally acceptable, nutritionally adequate diet through a sustainable food system that maximizes a 
community's self-reliance and a social justice (Thiengkamol, 2011: 162). Fast food becomes common among consumers. Most of teenagers and young people consume unhealthy fast food. (Wartornpaibul, 2014: 256).

Surat Thani, the largest province of the South of Thailand, is a southern Thai coastal province situated on the edge of the Gulf of Thailand, with many natural resources, historical, and cultural attractions, as well as Thailand's most famous islands including Koh Samui, Koh Phangan, Koh Tao, and the Mu Koh Ang Thong Marine National Park. Most of the resident population is engaged in subsistence agriculture, livestock and fisheries. The province is potential in hospitality and tourism. Its economic growth, expansion of infrastructure, and human activities of livelihood are leading to environmental degradation, reduction of natural resources and risk of food security. Human use of the physical environment and natural resources is often excessive and uncontrolled (Jamaluddin, et al., 2009: 258; Praneetham and Thathong, 2012a: 6; Praneetham, et al., 2012b: 535). Food security can affects human's way of living. The consumption behavior of high-calorie, nutritionally poor, and unhealthy fast food is bad for health. Moreover, the inability to consistently access adequate amounts of nutritious food will lead to inactive and unhealthy lives. Proper food consumption behavior and food security management will lead to self-reliance and social justice. Therefore, the researchers are interested in studying inspiration, behavior and the factors that influence the consumers' behavior on food security management. The four components of inspiration in food security management for this research comprise of inspiration in term of person as role model, inspiration in term of impressive event, inspiration in term of impressive environment, and inspiration in term of media receiving.

\section{The Purposes of the Research}

The objectives of this research were:

2.1 To study inspiration and consumption behavior of consumers for enhanced food security management.

2.2 To investigate factors influencing food security management behavior of consumers.

2.3 To study the relationship between inspiration and behavior of consumers on food security management.

\section{Methodology}

The research design was implemented in steps by step as follows:

3.1 The quantitative research was done by using questionnaire as tool for data collection. The population in this study was 171,712 people in the Surat Thani province, Thailand. The simple random sampling technique was employed to select 400 people in Muang district, Surat Thani province.

3.2 The research instrument was the close-ended questionnaire with a five-level rating scales on inspiration and behavior in food security management was distributed to 400 people in 2014. The questionnaire was based on comprehensive literature reviews. The content and structural validity were determined by Item Objective Congruent (IOC) with 3 experts in the aspects of psychology, social research methodology and environmental education. The reliability was done by collecting the sample group from 50 consumers. The reliability was determined by the Cronbach's Alpha while the reliability test of the whole questionnaire was 0.934 . The final questionnaire consisted of four parts and total number of questions was 52 items.

3.3 The mean, frequency, percentage, standard deviation, t-test, One-Way-ANOVA and Pearson's Product Moment Correlation were used to analyze the data.

\section{Results}

The sampled respondents of this study were 400 consumers in the Surat Thani province, Thailand. Most of them were female and single. The ages were between 21-29 years old and most had education at Bachelor level, as shown in table 1. 
Table 1: Demographic Characteristics of Respondents

\begin{tabular}{l|c|c}
\hline \hline \multicolumn{3}{c}{ Characteristics } \\
\hline Sex & Frequency & Percent \\
\hline Male & 181 & 45.3 \\
Female & 219 & 54.8 \\
\hline Total & 400 & 100.0 \\
\hline \hline Age & Year & Percent \\
\hline $15-20$ Years old & 41 & 10.3 \\
21-29 Years old & 144 & 36.0 \\
30-39Years old & 103 & 25.8 \\
40-49Years old & 73 & 18.3 \\
50-59Years old & 32 & 8.0 \\
More than 60 Years old & 7 & 1.8 \\
\hline Education Level & Frequency & Percent \\
\hline Primary school & 38 & 9.5 \\
High school/ Secondary school or equal level & 71 & 17.8 \\
Diploma or equal level & 58 & 14.5 \\
Bachelor & 207 & 51.8 \\
Higher than Bachelor & 26 & 6.5 \\
\hline Marital Status & Frequency & Percent \\
\hline Single & 188 & 47.0 \\
Marriage & 201 & 50.3 \\
Separate & 9 & 2.3 \\
Divorce/Widow & 2 & 0.5 \\
\hline Total & 400 & 100.0 \\
\hline \hline
\end{tabular}

Table 2: Results of the inspiration in food security management

\begin{tabular}{|l|c|c|c|}
\hline Inspiration in food security management & $(\bar{x})$ & SD & Meaning \\
\hline Inspiration in term of person as role model & 3.80 & 0.72 & good \\
\hline Inspiration in term of impressive event & 3.79 & 0.72 & good \\
\hline Inspiration in term of impressive environment & 3.82 & 0.69 & good \\
\hline Inspiration in term of media receiving & 3.67 & 0.74 & good \\
\hline Total & 3.77 & 0.60 & good \\
\hline
\end{tabular}

From Table 2, the finding found that the consumers' inspiration for enhanced food security management was at "good" level (Mean $=3.77$ ). The result showed that the King Bhumibol is inspirational role model for Thai people and his projects also motivate them on food security management.

Table 3: Results of the behavior on food security management

\begin{tabular}{|l|c|c|c|}
\hline Food security topics & $(\bar{x})$ & SD & Meaning \\
\hline Availability & 3.65 & 0.57 & good \\
\hline Access & 3.25 & 0.43 & moderate \\
\hline Utilization & 3.73 & 0.55 & good \\
\hline Stability & 3.63 & 0.54 & good \\
\hline Total & 3.57 & 0.35 & good \\
\hline
\end{tabular}

From Table 3, the result showed that, overall, the consumers' behavior on food security management was at "good" level (Mean $=3.57$ ). Based on data analysis, consumers' behavior on food utilization was at the highest level compared to other behavior (Mean $=3.73$ ), followed by food availability (Mean $=3.65$ ), food stability (Mean $=3.63$ ), and lastly food access (Mean $=3.25)$. 
Table 4: Comparison between the behavior of male and female consumers on food security management

\begin{tabular}{|l|c|c|c|c|c|c|}
\hline \multirow{2}{*}{ Food security topics } & \multicolumn{2}{|c|}{ Male } & \multicolumn{2}{c|}{ Female } & \multirow{2}{*}{$\mathrm{t}$-value } & \multirow{2}{*}{$\mathrm{p}$-value } \\
\cline { 2 - 5 } & $\overline{(})$ & SD & $(\bar{x})$ & SD & & \\
\hline Availability & 3.58 & 0.60 & 3.70 & 0.53 & -2.135 & $.033^{*}$ \\
\hline Access & 3.19 & 0.42 & 3.30 & 0.42 & -2.640 & $.009^{* *}$ \\
\hline Utilization & 3.76 & 0.59 & 3.71 & 0.51 & .820 & .413 \\
\hline Stability & 3.64 & 0.56 & 3.63 & 0.54 & .249 & .803 \\
\hline Total & 3.54 & 0.38 & 3.59 & 0.33 & -1.222 & .222 \\
\hline
\end{tabular}

* Significant at the 0.05 level, * * Significant at the 0.01 level

From Table 4, judging from the test values (t-test), it can be derived that, overall, the variable sex did not affect the consumers' behavior on food security management. However, it should be noted, that only food utilization and food stability topics showed no difference of food security management behavior of male and female consumers. While, the variable sex affected the consumers' behaviors on food access and food availability with the difference of statistically significance level of 0.01 and 0.05 respectively.

Table 5: Comparison of the consumers' behavior on food security management by education

\begin{tabular}{|l|c|c|c|c|c|}
\hline Source of Variation & Sum of squares & Df & Mean Square & $\mathrm{F}$ & p-value \\
\hline Between Group & 1.264 & 4 & .316 & 2.551 & $.039^{*}$ \\
Within Group & 48.948 & 395 & .124 & & \\
Total & 50.213 & 399 & & & \\
\hline
\end{tabular}

* Significant at the 0.05 level

Table 5 indicated the results of One-way ANOVA showed that there was different of average scores about behavior on food security management of consumers. This meant that the level of education influence on food security management.

The LSD was used for analysis of each pair of education level to determine the mean score differences of their behavior on food security management. It showed that the consumers' behavior of Primary school and Bachelor level were statistical different $(p<0.05)$ (Mean $=3.66$ and 3.70$)$, and of Bachelor and Higher than Bachelor were also statistical different $(p<0.05)$ (Mean $=3.70$ and 3.57$)$, all as illustrated in Table 6 .

Table 6: LSD analysis of each pair comparisons

\begin{tabular}{|l|c|c|c|c|c|}
\hline Behavior on food security management & $(\mathrm{PS})$ & $(\mathrm{SS})$ & $(\mathrm{VS})$ & $(\mathrm{BC})$ & $(\mathrm{HBC})$ \\
\hline Primary school (PS) (3.66) & $(3.66)$ & $(3.58)$ & $(3.52)$ & $(3.70)$ & $(3.57)$ \\
\hline Secondary school / or equal level (SS) (3.58) & - & .0839 & .0804 & $.1419^{*}$ & -.0363 \\
\hline Vocational school / diploma / or equal level (VS) (3.52) & & - & -.0035 & .0579 & -.1202 \\
\hline Bachelor (BC) (3.70) & & & - & .0615 & -.1167 \\
\hline Higher than Bachelor (HBC) (3.57) & & & & - & $-.1782^{*}$ \\
\hline
\end{tabular}

* Significant at the 0.05 level

The results above showed that the consumers who had different education had different behavior on food security management.

Table 7: Comparison of the consumers' behavior on food security management by age

\begin{tabular}{|l|c|c|c|c|c|}
\hline Source of Variation & Sum of squares & Df & Mean Square & $F$ & $p$-value \\
\hline Between Group & 3.345 & 5 & .669 & 5.623 & $.000^{*+*}$ \\
Within Group & 46.868 & 394 & .119 & & \\
Total & 50.213 & 399 & & & \\
\hline
\end{tabular}

** Significant at the 0.01 level

Table 7 indicated that the consumers' behavior on food security management was significantly different between age 
groups with the difference of statistically significance level of 0.01 . It showed that the consumers' behavior of age between 30-39 and 40-49 years old were better than those between 15-20 years old and 21-29 years old, all as illustrated in Table 8.

Table 8: LSD analysis of each pair comparisons

\begin{tabular}{|l|c|c|c|c|}
\hline Behavior in food security management & $\begin{array}{c}15-20 \text { years old } \\
(3.50)\end{array}$ & $\begin{array}{c}21-29 \text { years old } \\
(3.47)\end{array}$ & $\begin{array}{c}30-39 \text { years old } \\
(3.63)\end{array}$ & $\begin{array}{c}40-49 \text { years old } \\
(3.70)\end{array}$ \\
\hline 15-20 years old $(3.50)$ & - & .0254 & $-.1389^{\star}$ & $-.2050^{\star \star}$ \\
\hline $21-29$ years old $(3.47)$ & & - & $-.1643^{* *}$ & $-.2303^{\star *}$ \\
\hline $30-39$ years old (3.63) & & & - & .1181 \\
\hline $40-49$ years old $(3.70)$ & & & & - \\
\hline
\end{tabular}

** Significant at the 0.01 level

Table 9: Comparison of the consumers' behavior on food security management by marital status

\begin{tabular}{|c|c|c|c|c|c|}
\hline Source of Variation & Sum of squares & Df & Mean Square & $\mathrm{F}$ & $p$-value \\
\hline \begin{tabular}{|l} 
Between Group \\
Within Group \\
Total
\end{tabular} & $\begin{array}{c}1.633 \\
48.580 \\
50.213\end{array}$ & $\begin{array}{c}3 \\
396 \\
399\end{array}$ & $\begin{array}{l}.544 \\
.123\end{array}$ & 4.438 & $.004^{* *}$ \\
\hline
\end{tabular}

From Table 9, the result showed that the consumer who had different marital status had the difference of behavior level in food security management $(p>0.01)$. It indicated that the behaviors on food security management of married consumers were better than single consumer, as illustrated in Table 10.

Table 10: LSD analysis of each pair comparisons

\begin{tabular}{l|l|c|c|c|c|}
\hline Behavior in food security management & Single (3.51) & Married (3.63) & Separated (3.44) & Divorced (3.52) \\
\hline Single (3.51) & - & $-.1229^{\star \star}$ & .0716 & -.0099 \\
\hline Married (3.63) & & - & .1945 & .1130 \\
\hline Separated (3.44) & & & - & -.0815 \\
\hline Divorced (3.52) & & & & - \\
$* \star$
\end{tabular}

The results above showed that the consumers who had different age and marital status had different behavior on food security management.

Table 11: Correlation between consumers' inspiration and behavior on food security management

\begin{tabular}{|c|c|}
\hline Variable & Behavior \\
\hline Inspiration & $.400^{* *}$ \\
\hline \multirow{2}{*}{ ** Significant at the 0.01 level }
\end{tabular}

From Table 11, the results illustrated the inspiration of consumers were significantly correlated with behavior on food security management $(p<0.01)$. In other word, consumers' inspiration and behavior on food security management correlated with each other.

\section{Discussion}

The finding indicated that the consumers' inspiration for enhanced food security management was at "good" level. The King Bhumibol is inspirational role model for Thai people and his projects also motivate them on food security management. This related to survey of Teungfung and Kerdlapee (2013: 69) revealed that the influence factors on students' consumption behavior were attitude, motivation and the Royal Sufficiency Economy Philosophy. Field study in successful communities or project areas using the Royal Sufficiency Economy Philosophy should be encouraged for 
better understanding. Phaungsri (2007) also mentioned that perception of the King's sufficient economy helps people understand the concept of enough, reasonable, and self immunity and can apply to their daily life to get rid of the poverty. Meanwhile, communication efforts and the provision of information can influence everyone to be involved with sustainable food chains (Vermeir and Verbeke, 2006: 188).

The consumers' behavior on food security management was at "good" level. The finding revealed that people in Surat Thani Province had sufficient food for consumption and no need to borrow or ask for help from friends or relatives. Consumers were much concerned about food safety, cleanliness, and nutritious and delicious meals. They stayed closely to natural resources and the environment and their food derived from production, natural food sources or their field (Mungjit, et al., 2012, Chaiumporn and Wimonwat, 2013: 3).

Furthermore, inspiration in food security management influenced behavior on food security management (Teunfung and Kerdlapee, 2013; Tumpracha, et al., 2012a). While the variable sex affected the consumers' behaviors on food access and food availability with the difference of statistically significance level of 0.01 and 0.05 respectively. It could be concluded that gender had correlation with behaviors (Phaungsri, 2007; Praneetham and Thathong, 2012a: 10). As the difference of education level was the main factor affecting consumers' behavior, relevant authorities who are involved in education planning should integrate the Royal Sufficiency Economy Philosophy in all subjects, so that students would have better knowledge, understanding and awareness concerning sufficiency principle, which can lead to a high level of concern for food security and application (Phaungsri, 2007, Praneetham and Thathong, 2012a: 9, Teunfung and Kerdlapee, 2013: 68). People should be concerned about the future of their children (Chaiumporn and Wimonwat, 2013: 3). Youth need to change their consumption behavior to prevent childhood obesity. They should avoid fast food consumption and consume more nutritious food (Wilson, et al. 2008; Tumpracha, et al. 2012a: 635). Everyone must cooperate with each other to solve the problems by enhancing and increasing more production of food crops and animals, growing vegetable and raising fish by themselves to attain food security. Youths should participate in the food management process for the benefits of future food security (Chaiumporn and Wimonwat, 2013: 3). Public policy and marketing recommendations can stimulate sustainable food consumption among the young, in order to set up the main market of sustainable food products in the future (Vermeir and Verbek, 2006: 188).

\section{Conclusions}

We conclude that if a person has high motivation and inspiration in food security management, he will also behave in food security management properly. Perceiving information, attitude and awareness influence behavior changing. Hence, it is needed to promote informative information, better knowledge about food security and safety, stronger awareness and good attitude of the food security which can lead to positive change in behavior. Human, especially youth need to access adequate nutrition, clean delicious food and free from chemicals and toxins at all time. Food insecurity will affect health and quality of life during the ageing process and impact on ongoing old-age. Low quantity and poor quality of foods will cause malnutrition and can lead to illness. Cooperation and participation on natural resources and environment conservation can help reduce the risk of food shortages and conserve resources optimally and sustainably. Therefore, everyone should encourage and support the community to help themselves in food management for enhanced food security and safety. Moreover, sufficient principle should be promoted to be applied in everyday life according to His Majesty the King's philosophy.

\section{Acknowledgement}

The authors would like to acknowledge financial support from Suratthani Rajabhat University. Any errors are the responsibility of the authors.

\section{References}

Beddington, J., Asaduzzaman, M., Fernandez, A., Clark, M., Guillou, M., Jahn, M., Erda, L., Mamo, T., Van Bo, N., Nobre, C.A., Scholes, R., Sharma, R., \& Wakhungu, J. (2011). Achieving food security in the face of climate change: Summary for policy makers from the Commission on Sustainable Agriculture and Climate Change. CGIAR Research Program on Climate Change, Agriculture and Food Security (CCAFS). Copenhagen, Denmark.

Braun, J., Fan, S., Meinzen-Dick, R., Rosegrant, M., \& Pratt, A. (2008). International Agricultural Research for Food Security, Poverty Reduction, and the Environment: What to Expect from Scaling Up CGIAR Investments and "Best Bet" Programs. International Food Policy Research Institute (IFPRI). Washington, DC, USA.

Canadian International Development Agency. (2014). Increasing Food Security. CIDA's Food Security Strategy. [Online] 
Available: http://www.acdi-cida.gc.ca/INET/IMAGES.NSF/vLUImages/Youth-and-Children/\$file/food-security-strategy-e.pdf (November 25, 2014)

Chaiumporn, S., \& Wimonwat, T. (2013). Food Management at Family Level according to Muslim Way of Life and the Mobilization Process to Attain Food Security in the Family : A Study of Ban Cha Jai Community (Fictitious Name), Chaiyo District, Ang Thong Province. Journal of Social Development, 15(2), 3-16.

Food and Agriculture Organization (FAO). (2006). Food Security: Policy Brief. June. Issue 2, 1-4.

Jahi, J. M., Arifin, K., Aiyub, K., \& Awang A. (2009). Development, environmental degratation and environmental management in Malaysia. European Journal of Social Sciences, 9(2), 257-264.

Mungjit, T., Keowan, B., \& Yooprasert, B. (2012). Potential Strengthen Guidelines of Food Security in Mae Surin Village, Khun Yuam District, Mae Hong Son Province. The 2nd STOU Graduate Research Conference, 1-13.

Nelson, G., Rosegrant, M., Palazzo, A., Gray, I., Ingersoll, C., Robertson, R., Tokgoz, S., Zhu, T., Sulser, T., Ringler, C., Msangi, S., \& You, L. (2010). Food Security, Farming, and Climate Change to 2050 : Scenarios, Results, Policy Options. International Food Policy Research Institute (IFPRI). Washington, DC, USA.

Phaungsri, C. (2007). A study on the sufficient economy appliance for the people in Bangkok and circumference. Master thesis in International Business, Graduate School, Rajamangala University of Technology Thanyaburi.

Pongsrihadulchai, A., Wattanatchariya, S., Photiyarach, S., \& Supawan, D. (2013). Food and Energy Security of Thailand. International Institute for Trade and Development. Bangkok: ID All Digital Print.

Praneetham, C., \& Thathong, K. (2012). Attitudes and Behaviors of High School Students in Vientiane, Lao People's Democratic Republic, towards the Environment. European Journal of Social Sciences, 35 (1), 5-12.

Praneetham, C., Thiengkamol, N., Thathong, K., \& Thiengkamol, T. (2012). Factors Affecting Villagers Participation in Community Environment Development. Mediterranean Journal of Social Sciences, 3 (11), 535-540.

Renliang, L. (2013). China's Food Security Policy. Journal of Social Development, 15(2), 101-112.

Teunfung, R., \& Kerdlapee, J. (2013). Consumption Behavior of Undergraduate Students Following the Royal Sufficiency Economy Philosophy: A Case Study at Rajamangala University of Technology Suvarnabhumi Nontaburi Center. Journal of Social Development, 15(2). 67-95.

Thiengkamol, N. (2011). Development of a Food Security Management Model for Agricultural Community. Canadian Social Science, 7 (5), 162-166.

Thiengkamol, N. (2012). Food Security Management of Agriculture Community. MSU Research Digest, 1 (2), 35-42.

Tumpracha, K., Thiengkamol, N., Thiengkamol, C. (2012a). Causal Relationship of Food Security Management. Mediterranean Journal of Social Sciences, 3 (11), 625-636.

Tumpracha, K., Thiengkamol, N., Thiengkamol, C. (2012b). Development of Food Security Management Model through PAIC Process. Mediterranean Journal of Social Sciences, 3 (11), 311-318.

Wartornpaibul, T. (2014). Consumption Behavior : Consumerism Food and Health - Conscious Food. Panyapiwat Journal, 5(2), 255264.

Vermeir, I., \& Verbeke, W. (2006). Sustainable Food Consumption: Exploring the Consumer "Attitude - Behavioral Intention" Gap. Journal of Agricultural and Environmental Ethics, 19, 169-194

Wilson, A. M., Magarey, A. M., \& Mastersson, N. (2008). Reliability and relative validity of a child nutrition questionnaire to simultaneously assess dietary patterns associated with positive energy balance and food behaviours, attitudes, knowledge and environments associated with healthy eating. International Journal of Behavioral Nutrition and Physical Activity, vol. 5, January 2008. 